\title{
Getting cosy in freshwater: assumed-to-be brackish pike are not so brackish after all
}

\author{
Birnie-Gauvin, Kim; Højrup, Lasse Birch; Kragh, Theis; Jacobsen, Lene; Aarestrup, Kim
}

\section{Published in:}

Ecology of Freshwater Fish

Link to article, DOI:

10.1111/eff.12460

Publication date:

2018

Document Version

Peer reviewed version

Link back to DTU Orbit

Citation (APA):

Birnie-Gauvin, K., Højrup, L. B., Kragh, T., Jacobsen, L., \& Aarestrup, K. (2018). Getting cosy in freshwater: assumed-to-be brackish pike are not so brackish after all. Ecology of Freshwater Fish, 28(3), 376-384. https://doi.org/10.1111/eff.12460

\section{General rights}

Copyright and moral rights for the publications made accessible in the public portal are retained by the authors and/or other copyright owners and it is a condition of accessing publications that users recognise and abide by the legal requirements associated with these rights.

- Users may download and print one copy of any publication from the public portal for the purpose of private study or research.

- You may not further distribute the material or use it for any profit-making activity or commercial gain

- You may freely distribute the URL identifying the publication in the public portal 
${ }^{1}$ DTU AQUA, National Institute of Aquatic Resources, Section for Freshwater Fisheries Ecology,

Technical University of Denmark, Vejlsøvej 39, 8600 Silkeborg, Denmark

${ }^{2}$ Freshwater Biology, University of Copenhagen, Universitetsparken 4, 2100 København Ø,

Denmark

${ }^{\dagger}$ Author is deceased. 

1

Abstract:

Pike (Esox lucius) occupy coastal streams and rivers of the Baltic Sea, where they attain large sizes ( $>5 \mathrm{~kg}$ ). These large sizes are perhaps due to the fact that they can tolerate relatively high salinities and can thus forage in the nearby more productive brackish environments. In an attempt to quantify the extent to which pike utilize brackish environments, and to provide some insight on the underlying causes for brackish water migrations, we tagged 30 pike from a western Baltic river with acoustic transmitters and were able to track 21 individuals for one year. Based on local anglers, this population was assumed to be brackish in nature, where individuals underwent freshwater migrations to spawn. Our findings however suggest that the smallest and most active individuals make short exits into brackish waters, and do so on rare occasions. Our results further indicate that neither sex nor size are related to activity level. We suggest that these patterns reflect two distinct behaviours - active and passive - and that large pike can be supported by the food availability in the river, without the need to venture into coastal zones, thus defying the conventional view that Baltic pike are all brackish in nature.

Keywords: brackish, Esox lucius, ecosystem functioning, freshwater, reproductive migrations 


\section{Introduction:}

Northern pike (Esox lucius, Linnaeus) is a signature apex predator of many freshwater ecosystems in the Northern Hemisphere. As such, this species has a great top-down impact on the structure, abundance and composition of prey fish within a system (Johnson 1966; Skov et al. 2002; Craig 2008), and thus acts as an important regulator of fish assemblages, including on nutrient levels and cycles. Evidence suggests that pike can affect the behaviour and movements of prey fish (Jacobsen and Perrow 1998), and alter foraging activity (Bean and Winfield 1995; Jacobsen and Perrow 1998), with important ecosystem-scale impacts, including nutrient levels and cycles (Skov et al. 2011). The role of pike in local ecosystem functioning implies its ecological importance in temperate freshwater systems.

Recently however, pike populations - like many other freshwater fish populations - have been exposed to extensive habitat changes and other perturbations, largely stemming from anthropogenic pressures (Craig 2008). This has resulted in considerable research on pike ecology in recent times, especially geared towards investigating the implications of habitat and food chain alterations for conservation and management purposes. Furthermore, given their prized value as a sport fish, Northern pike have received much attention for their performance associated with various fishing gear, as well as their survival during catch-and-release practices (e.g. Arlinghaus et al. 2009).

Northern pike have been found living in both fresh (i.e. rivers and lakes) and brackish waters (low salinity, estuary-like; Harvey 2009). Despite their common use in research and widespread distribution however, few aspects of the species' life history appear constant across all populations. Instead, research on pike seems to support a more diverse and flexible life history, with different populations behaving differently in space and time. For example, there is evidence suggesting that under laboratory conditions pike activity peaks at approximately $20^{\circ} \mathrm{C}$ and 
decreases gradually at lower temperatures (Casselman 1978). Given these findings, a lower activity level during winter (in comparison to summer) is expected. This is both corroborated (e.g. Kobler et al. 2008) and contradicted (Jepsen et al. 2001; Koed et al. 2006), supporting the idea that pike can display flexible behaviour, perhaps as a function of their specific environment.

Fish movement is arguably the most important behaviour, as it regulates foraging activity and efficiency, predator avoidance and refuge seeking, as well as habitat selection (Shreck et al. 1997). Movement is thus an important determinant of fish fitness as it is associated with various fitness endpoints such as growth, reproductive success and survival (Scherer 1992; Schreck et al. 1997; Barton et al. 2002). Understanding the spatial and temporal movements of a species can thus focus management efforts and make them more profitable. To that effect, understand the underpinning mechanisms behind the flexibility in pike life history may also help improve the current management approach.

Several studies have investigated pike movement, and have found that pike can be abundant in coastal areas with low salinity. This is the case in Denmark, Finland, Sweden and Germany for example, where pike are often found in coastal streams and rivers of the Baltic Sea (Craig 2008), with salinities approaching their upper tolerance limit. In the Baltic Sea, two Swedish pike populations were found to reproduce in different environments: one displaying an anadromous behaviour, with obligate freshwater spawning, and the other spawning in brackish Baltic waters (Westin and Limburgh 2002). This reproductive behaviour in brackish waters has also been observed in Finland for example (Lappalainen et al. 2008). Pike eggs and fry have also been shown to tolerate high salinities (Jørgensen et al. 2010). It is thus perhaps not surprising that pike spawn in brackish waters. Nonetheless, understanding the drivers and the extent to which this flexible behaviour is present in pike populations is necessary to understand population dynamics, and advise adequate management measures. In this study, we aimed to investigate the movements of a Danish 
pike population inhabiting a coastal river flowing into the Baltic Sea. Based on local angler knowledge (from local angling clubs for example), brackish-water environments were expected to be of considerable importance for this population. This idea stems from the fact that this pike population is composed of very large individuals, and that feeding strictly in a small freshwater river is thought to be insufficient for individuals to attain such sizes. In fact, this population has long been assumed to be a brackish-water population, with individuals journeying into freshwater only to spawn (i.e. anadromous). We tested this hypothesis by tagging and tracking pike with acoustic transmitters over the course of one year.

\section{Materials and Methods}

\section{Study area}

River Tryggevælde, southeast Sealand, Denmark (Figure 1), is home to a population of Northern pike comprising many large individuals (> $5 \mathrm{~kg}$ ), supporting a valuable recreational angling community. The pike population has long been assumed to consist of mainly brackish-water individuals, driving the population's large individual mass and condition factor. The river is approximately 45 km long, and flows into Køge Bay which gives into the Baltic Sea. Our study focused on the 12 downstream-most river kilometres, and the river outlet (river mouth, where the river exits into the bay).

\section{Fish}

Pike were caught between 9 March and 11 March 2014, either by electrofishing $(n=18)$ or angling ( $n=12$ ) along the banks of the river between 500 and $5000 \mathrm{~m}$ from the outlet (within the receiver range, see below). Individuals were kept in carp sacks or a large live-well placed in the river for up 
121 to 24 hours. For the procedure, fish were anesthetized with $0.05 \mathrm{mg} \mathrm{l}^{-1}$ of 2-phenoxyethanol in

122 freshwater. Fish were then weighed, measured, sexed, and implanted with an acoustic transmitter

123 (V13-1L, Vemco, $13 \mathrm{~mm}$ in diameter, $36 \mathrm{~mm}$ in length, $11 \mathrm{~g}$ in air, Nova Scotia, Canada). The

124 incision was closed with two absorbable sutures (Vicryl 3-0 FS-2, Ethicon, Scotland). The

125 procedure took between 3 and 5 minutes. Fish were then placed in a tank with fresh river water, and

126 later released on either 10 March or 11 March 2014 at their site of capture. See Table 1 for

127 summary data.

128

129 Environmental variables

130 Water temperature was monitored every 30 minutes using a temperature logger (HOBO Pendant

131 Temperature/Light Data Logger 8K, UA-02-08) at the outlet (82m from the outlet). Salinity was

132 measured once per hour using a conductivity logger (HOBO Conductivity Data Logger, UA-002-C)

133 at two positions (82 $\mathrm{m}$ and $2818 \mathrm{~m}$ from the outlet). Water discharge data were obtained from the

134 Ministry of the Environment using a logger situated approximately $16 \mathrm{~km}$ from the outlet.

135 Discharge was adjusted for size of the water catchment. Loggers were positioned in the river and outlet on 25 June 2014, approximately 108 days after fish were tagged and released in the river.

\section{Tracking movements}

139 Movements were tracked with 12 automatic listening stations (VR2 receivers, Vemco, Nova Scotia, 140 Canada) placed strategically along the river and river outlet to detect fish movement within the river,

141 but also to detect fish as they moved in and out of the river and into the bay (Figure 1). Range testing 142 using a ‘dummy’ tag took place before fish were released, and ranged between 60 and 200m. Signal 143 detection efficiencies were between 70 and $100 \%$. At locations where detection efficiencies were 
lower, two receivers were positioned nearby with overlapping ranges (see Table 2 for details on position and efficiency of receivers).

Of the 30 tagged pike, 21 (16 females and 5 males) were detected for one full year. Only those individuals were used for movement analyses. The remaining 9 individuals either died (1 female and 4 males) or disappeared from the study area (2 females and 2 males).

We measured the number of exits out of the river performed by each fish as periods when fish were detected at receivers outside the river for 1 hour or more. One hour was chosen as the cutoff after initial investigation of the data, which suggested fish seldom spent less than 1 hour when venturing out. Furthermore, a shorter cut-off may not have been biologically significant in terms of feeding, while a longer cut-off may have removed valuable data. Total distance moved was determined as the sum of the distance between different receivers where the fish was detected in sequence. At times when a fish was detected simultaneously at two receivers, the fish's position was assumed to be midway between the two receivers. Mean daily activity was then calculated as the total distance travelled, divided by the length of the study period for each fish (i.e., time between first and last detection), regardless of days without detections. This approach results in the minimum mean daily activity.

\section{Statistical analyses}

We first tested whether fish captured by angling differed from those being electrofished using a series of ANOVAs to test for differences in mean daily activity and fate (i.e., survived, disappeared or dead). Given the general size difference among males and females, sex was used as a covariate in the subsequent analyses but capture method was not, given that the method did not affect activity levels or fate (i.e., capture method did not affect whether a fish died or disappeared). Furthermore, given the collinear nature of mass and length, we used length only as a proxy for size for the analyses. 

model (GLM). Whether fish exited the river or not was modeled as a binary outcome (GLM, logit

170

link) with size, sex and mean daily activity as model variables. The number of exits performed was modeled as a Gaussian-distributed variable (GLM, log link) with size, sex and mean daily activity as model variables. A final GLM was used to examine whether size, sex and mean daily activity affected the final fate of the fish. All statistical analyses were performed in R version 1.1.383 (R Core Team, 2013) using the ggplot2 (Wickham, 2009), lattice (Deepayan, 2008) and MASS (Venables \& Ripley, 2002) packages.

\section{Results}

Capture method did not affect mean daily activity and fate $(p>0.05)$. Out of 21 tagged individuals tracked for one year, 15 travelled into the bay for one hour or more, but only 2 of these individuals remained in the bay for more than 24 hours, and did so only once each.

Mean daily activity was not correlated to sex (GLM, Z $=-0.504, p>0.05)$ or length (GLM, $\mathrm{Z}=1.03, p>0.05$ ), though we note a trend for females being more active than males. Whether a fish exited the river was positively correlated to mean daily activity (GLM, Z = 1.89, $p<0.05$, Figure 2) but negatively correlated to length (GLM, $\mathrm{Z}=-2.05, p<0.05$, Figure 3 ). The number of exits from the river was not correlated to length, sex, or mean daily activity (GLM, $p>0.05$ ).

Pike generally spent most of their time in the lower stretches of the river (Figure 4). Periods when fish exited the river into the bay coincided with peaks in salinity in the river (between 6 and 10ppt, Figure 5). In fact, 14 of the 15 pike which exited the river did so either between 5 August to 8 August 2014 or 3 September to 6 September 2014.

\section{Discussion}


In this study, we show that in a population of Northern pike assumed-to-be brackish, individuals do move into brackish water (15 out of 21, $71 \%$ ), but generally stay there less than 24 hours. We found that of the individuals that did travel into brackish water, only 2 (13.3 \%) stayed in the bay for more than 24 hours, suggesting that in general, pike of this population do not utilize that environment nearly as much as was previously thought. This finding also suggests that the high growth rate observed in this population must be due to either high food availability within the river itself, or large influxes in prey items coming in from the bay with strong currents. This hypothesis is supported by the observation that smaller pike were more likely to exit into the bay and that pike generally spent more time in the lower reaches of the river.

We found no sex-bias in activity levels. Sex bias in activity is not uncommon in fish during the spawning season (cichlids, Taylor et al., 2003; salmonids, Bekkevold et al., 2004; Fraser et al., 2004), but not always the case. It has been suggested that this behaviour may be to reduce the risk of inbreeding; by having one sex move more than the other, the risks of inbreeding are greatly reduced. In pike, an increased movement by females has been suggested to be a form of homing behaviour in females to previously suitable spawning grounds (Koed et al., 2006). The females may move more to regain that area and thus gain a competitive advantage over it. Females have also been observed to move more than males regardless of the season (Jepsen et al., 2001), perhaps in an attempt to forage more often and attain a larger size and greater reproductive potential (Casselman, 1978; Bregazzi and Kennedy, 1980; Casselman, 1996). While our approach does not allow us to adequately distinguish activity levels over time (continuous manual tracking, as done in Koed et al. 2006 is more effective), our findings may suggest that in this river, adequate spawning and foraging areas are plentiful and females do not need to move extensively to find them. The hypothesis that food abundance is high and may not require active foraging is supported by the fact that size was not related to mean daily activity, and females were larger than males. This may reflect different 
behavioural tactics across individuals rather than sex- and size-driven differences (e.g., Thomaz et al., 1997).

Our findings on activity levels are not unlike a number of previous studies carried out on pike inhabiting lakes and reservoirs which showed mostly sedentary behaviour during the nonspawning season (e.g., Cook and Bergersen, 1988). While some individuals did exhibit high activity levels, most exhibited sedentary behaviours with infrequent peaks in activity. However, individuals with high activity levels were significantly more likely to make exits into the bay, perhaps suggesting a more active foraging tactic. Lower activity levels may be associated with an ambush predation tactic. These two contrasting behaviours are not unusual in E. lucius. Individuals of the same populations have been observed to have widely different behavioural patterns. For example, individuals from a western Baltic population living in transitional waters were found to either reside in a lagoon year-round, or to spawn in the lagoon and migrate into freshwater during the nonspawning period (Jacobsen et al., 2017). The authors found that these behaviours were consistent within individuals over time, and may reflect individual variation in home ranges and resource allocation/optimisation. Our findings support this idea, with active individuals undergoing short journeys into the bay, and less active individuals remaining in freshwater. The observation that smaller fish were more likely to exit into the bay may also support two behavioural tactics. For example, it is possible that small individuals exit into the bay to acquire food actively if larger, more dominant individuals are feeding in freshwater, and preventing smaller individuals from doing so.

Exits into Køge Bay did not appear to be related to temperature or discharge, but coincided with higher salinities. While 14 of the 15 individuals that travelled into the bay did so either between 5 August to 8 August, or 3 September to 6 September, salinity was still high between the two periods and peaked in early September (15ppt), but no pikes were detected leaving the river 
during that time. This suggests that salinity itself is not a driver for migrations into brackish water. Instead, it is more likely that strong winds which pushed saline water into the bay (Fischer and Matthäus, 1996) during that period brought with them prey items which the pike could feed on. The period between the two peak periods for exits into the bay may have been too saline for pike to tolerate, and may explain why the pike migrated back into freshwater. The return of salinity to more tolerable levels (8-10ppt) may have allowed active pike to return to the bay between 3 September to 6 September, where food items may have been more abundant than normal. Alternatively, it is also possible that prey items actively swam into the outlet of the river during periods of high salinity, exits into the bay.

past decades, likely reflecting a decline in the population of Baltic pike despite their flexible nature (Jacobsen et al., 2008; Lehtonen et al., 2009). While the specific causes for this decline remain unknown, poor recruitment (Nilsson 2006) and anthropogenic activities (including overfishing and habitat changes) are thought to be the main source (Jacobsen et al. 2008; Lehtonen et al., 2009). Our study supports the idea that pike have flexible life histories, which may provide this species with an advantage over other species with more strict life histories. Pike can utilize habitats with wideranging salinities, exhibit both active and passive behaviours, and may be more adaptable to future environmental changes caused by a human-dominated world, though current declines may suggest otherwise. Future research should consider investigating the underlying mechanisms that lead individuals in adopting one life history over another. Our findings do however suggest that longstanding, widely-accepted descriptions of pike populations as anadromous or primarily brackish may not be accurate. 


\section{Acknowledgments}

265 We wish to dedicate this manuscript to Dr. Lene Jacobsen (author of this writing) who dedicated her 266 career life to science, but who left us too soon. We also wish to thank Hans-Jørn Aggerholm 267 Christensen, Jes Dolby, Michael Holm and Morten Carøe, as well as the volunteer anglers for their 268 help in the field. This study was funded by the Danish Fishing Licenses.

269

\section{Author Contributions}

271 Conceived and carried out field work: LBH, TK, LJ and KA. Contributed materials for field work:

272 KA and LJ. Data compilation and analyses: KBG and LBH. Wrote the manuscript: KBG. 
References

289

290

291

292

293

294

295

296

297

298

299

300

301

302

303

304

305

306

307

308

309

310

311

Arlinghaus, R., Klefoth, T., Cooke, S. J., Gingerich, A., \& Suski, C. D. (2009). A combined laboratory and field study to understand physiological and behavioral disturbance and recovery from catch-and-release recreational angling in northern pike (Esox lucius). Fisheries Research, 97, 223-233.

Barton, B. A., Morgan, J. D., \& Vijayan, M. M. (2002). Physiological and condition-related indicators of environmental stress in fish. In Biological indicators of aquatic ecosystem stress. Edited by S. M. Adams. American Fisheries Society, Bethesda, pp. 111-148.

Bean, C. W., and Winfield, I. J. 1995. Habitat use and activity patterns of roach (Rutilus rutilus (L.)), rudd (Scardinius erythrophthalmus (L.)), perch (Perca fluviatilis L.) and pike (Esox lucius L.) in the laboratory: the role of predation threat and structural complexity. Ecology of Freshwater Fish, 4, 37-46.

Bekkevold, D., Hansen, M. M., \& Mensberg, K. L. D. (2004). Genetic detection of sex-specific dispersal in historical and contemporary populations of anadromous brown trout Salmo trutta. Molecular Ecology, 13, 1707-1712.

Casselman, J. M. (1978). Effects of environmental factors on growth, survival, activity, and exploitation of northern pike. American Fisheries Society, 11, 114-128.

Cook, M. F., \& Bergersen, E. P. (1988). Movements, habitat selection, and activity periods of northern pike in Eleven Mile Reservoir, Colorado. Transactions of the American Fisheries Society, 117, 495-502.

Craig, J. F. 2008. A short review of pike ecology. Hydrobiologia, 601, 5-16.

Deepayan, S. (2008)- Lattice: Multivariate Data Visualization with R. Springer, New York.

Fischer, H., \& Matthäus, W. (1996). The importance of the Drogden Sill in the Sound for major Baltic inflows. Journal of Marine Systems, 9, 137-157. 
Fraser, D. J., Lippé, C., \& Bernatchez, L. (2004). Consequences of unequal population size, asymmetric gene flow and sex-biased dispersal on population structure in brook charr (Salvelinus fontinalis). Molecular Ecology, 13, 67-80.

Harvey, B. (2009). A biological synopsis of northern pike (Esox lucius). Fisheries and Oceans Canada, Science Branch, Pacific Region, Pacific Biological Station, West Vancouver, Canada.

Jacobsen, L., \& Perrow, M. R. (1998). Predation risk from piscivorous fish influencing the diel use of macrophytes by planktivorous fish in experimental ponds. Ecology of Freshwater Fish, 7, 78-86.

Jacobsen, L., Bekkevold, D., Berg, S., Jepsen, N., Koed, A., Aarestrup, K., Baktoft, H., \& Skov, C. (2017). Pike (Esox lucius L.) on the edge: consistent individual movement patterns in transitional waters of the western Baltic. Hydrobiologia, 784, 143-154.

Jepsen, N., Beck, S., Skov, C., \& Koed, A. (2001). Behavior of pike (Esox lucius L.)> $50 \mathrm{~cm}$ in a turbid reservoir and in a clearwater lake. Ecology of Freshwater Fish, 10, 26-34.

Johnson, L. (1966). Consumption of food by the resident population of pike, Esox lucius, in Lake Windermere. Journal of the Fisheries Research Board of Canada, 23, 1523-1535.

Jørgensen, A. T., Hansen, B. W., Vismann, B., Jacobsen, L., Skov, C., Berg, S., \& Bekkevold, D. (2010). High salinity tolerance in eggs and fry of a brackish Esox Lucius population. Fisheries Management and Ecology, 17, 554-560.

Kobler, A., Klefoth, T., Wolter, C., Fredrich, F., \& Arlinghaus, R. (2008). Contrasting pike (Esox lucius L.) movement and habitat choice between summer and winter in a small lake. Hydrobiologia, 601, 1727.

Koed, A., Balleby, K., Mejlhede, P., \& Aarestrup, K. (2006). Annual movement of adult pike (Esox lucius L.) in a lowland river. Ecology of Freshwater Fish, 15, 191-199. 
Lappalainen, A., Härma, M., Kuningas, S., \& Urho, L. (2008). Reproduction of pike (Esox lucius) in reed belt shores of the SW coast of Finland, Baltic Sea: a new survey approach. Boreal Environment Research, 13, 370-380.

Lehtonen, H., Leskinen, E., Selen, R., \& Reinikainen, M. (2009). Potential reasons for the changes in the abundance of pike, Esox lucius, in the western Gulf of Finland, 1939-2007. Fisheries Management and Ecology, 16, 484-491.

R Development Core Team (2013). R: A language and environment for statistical computing. R Foundation for Statistical Computing, Vienna, Austria.

Skov, C., Perrow, M. R., Berg, S., \& Skovgaard, H. (2002). Changes in the fish community and water quality during seven years of stocking piscivorous fish in a shallow lake. Freshwater Biology, 47, 2388-2400.

Skov, C., Koed, A., Baastrup-Spohr, L., \& Arlinghaus, R. (2011). Dispersal, growth, and diet of stocked and wild northern pike fry in a shallow natural lake, with implications for the management of stocking programs. North American Journal of Fisheries Research, 31, 1177-1186.

Scherer, E. (1992). Behavioural responses as indicators of environmental alterations: approaches, results, developments. Journal of Applied Ichthyology, 8, 122-131.

Schreck, C. B., Olla, B. L., \& Davis, M. W. (1997). Behavioral responses to stress. In Fish Stress and Health in Aquaculture. Edited by G. W. Iwama, J. Sumpter, A. D. Pickering, and C. B. Schreck. Cambridge University Press, Cambridge, pp. 745-770.

Taylor, M. I., Morley, J. I., Rico, C., \& Balshine, S. (2003). Evidence for genetic monogamy and female-biased dispersal in the biparental mouthbrooding cichlid Eretmodus cyanostictus from Lake Tanganyika. Molecular Ecology, 12, 3173-3177. 
359 Thomaz, D. M. P. F., Beall, E., \& Burke, T. (1997). Alternative reproductive tactics in Atlantic salmon: factors affecting mature parr success. Proceedings of the Royal Society of London: Biological Sciences, 264, 219-226.

Venables, W. N., \& Ripley, B. D. (2002) Modern Applied Statistics with S. Fourth Edition. Springer, New York. populations of Esox lucius in the Baltic. Journal of Fish Biology, 61, 1647-1652. 
384 Table 1. Mean length and mass $( \pm$ SEM) of tagged pike (Esox lucius) according to sex (range in 385 bracket).

\begin{tabular}{|c|c|c|}
\hline & Females (19) & Males (11) \\
\hline \multirow{2}{*}{ Length (cm) } & $87.3 \pm 3.6$ & $76.2 \pm 1.3$ \\
& $(71.0-118.0)$ & $(66.1-82.6)$ \\
\hline \multirow{2}{*}{ Mass (kg) } & $6.02 \pm 0.8$ & $3.4 \pm 0.2$ \\
& $(3.0-14.2)$ & $(2.2-4.1)$ \\
\hline
\end{tabular}

Table 2. Position (m from river outlet), detection range (m) and detection efficiency (\%) of receivers upon range testing. Note: n/a indicates not applicable.

\begin{tabular}{|c|c|c|}
\hline $\begin{array}{c}\text { Receiver position (distance } \\
\text { from outlet in m) }\end{array}$ & $\begin{array}{c}\text { Detection range (downstream, } \\
\text { upstream in m) }\end{array}$ & $\begin{array}{c}\text { Detection efficiency } \\
\text { (downstream, upstream in \%) }\end{array}$ \\
\hline 12000 & Not measured & Not measured \\
\hline 7800 & Not measured & Not measured \\
\hline 5500 & 135,60 & 100,100 \\
\hline 5400 & 70,80 & 90,90 \\
\hline 2900 & 135, not measured & 70, not measured \\
\hline 2800 & 130,85 & 80,70 \\
\hline 150 & 85,85 & 100,100 \\
\hline 80 & 70,120 & 100,100 \\
\hline 30 in bay & $200, \mathrm{n} / \mathrm{a}$ & $100, \mathrm{n} / \mathrm{a}$ \\
\hline 100 in bay & $200, \mathrm{n} / \mathrm{a}$ & $100, \mathrm{n} / \mathrm{a}$ \\
\hline 560 in bay & $100, \mathrm{n} / \mathrm{a}$ & $100, \mathrm{n} / \mathrm{a}$ \\
\hline 800 in bay & $100, \mathrm{n} / \mathrm{a}$ & $100, \mathrm{n} / \mathrm{a}$ \\
\hline
\end{tabular}


Figures Captions

399

400

Figure 1. River Tryggevælde, Southern Sjælland, Denmark. The river runs for 45km before exiting 401 into Køge Bay. Red dots represent receiver placements.

402 Figure 2. Predicted probability (mean and 95\% confidence intervals) that acoustically tagged pike 403 (Esox lucius) exited River Tryggevælde (March 2014 - June 2015) as a function of an individual’s 404 mean daily activity (meters per day), assuming an average length of $85.0 \mathrm{~cm}$. Actual data are plotted as filled circles. More active fish were more likely to exit into the bay.

Figure 3. Predicted probability (mean and 95\% confidence intervals) that acoustically tagged pike 407 (Esox lucius) exited River Tryggevælde (March 2014 - June 2015) as a function of an individual's 408 length (cm), assuming an average daily activity of 242.9 meters per day. Actual data are plotted as filled circles. Smaller fish were more likely to exit.

Figure 4. Movements of pike (Esox lucius) from least (A) to most (U) active, detected by the receiver lines at approximately -580, -100, 3000, 5500, 8000 and 12000 meters from the river outlet. Red traces represent females $(n=16)$ and blue traces represent males $(n=5)$. The horizontal line represents the river outlet, with values $\geq 0$ in the river, and values $<0$ in the bay. Black dots represent exits into the bay longer than 1 hour. Note: fish A spent long periods at the river outlet (though still 415 in freshwater).

Figure 5. Environmental variables. Number of pike (Esox lucius) which exited the river (black bars) per day overlapped with temperature (top panel), salinity (middle panel) and discharge (lower panel) between March 2014 and June 2015. 


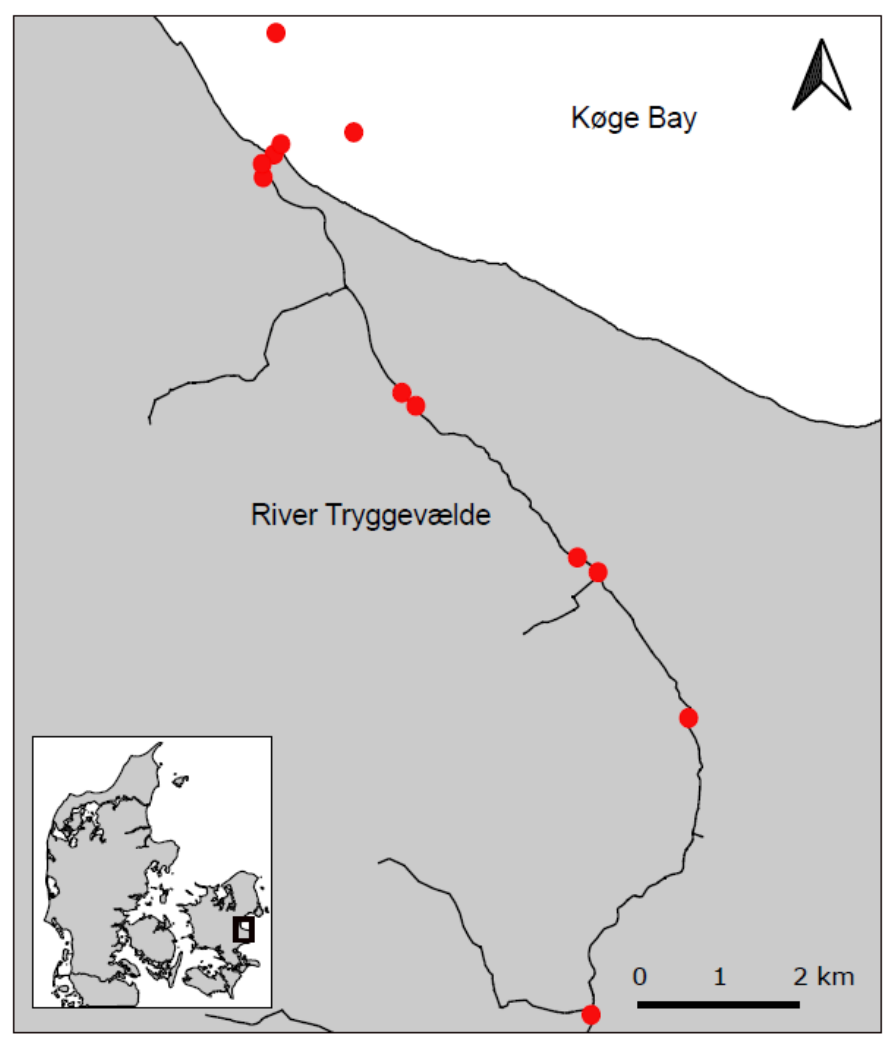

$420 \quad$ Figure 1

421

422

423

424 


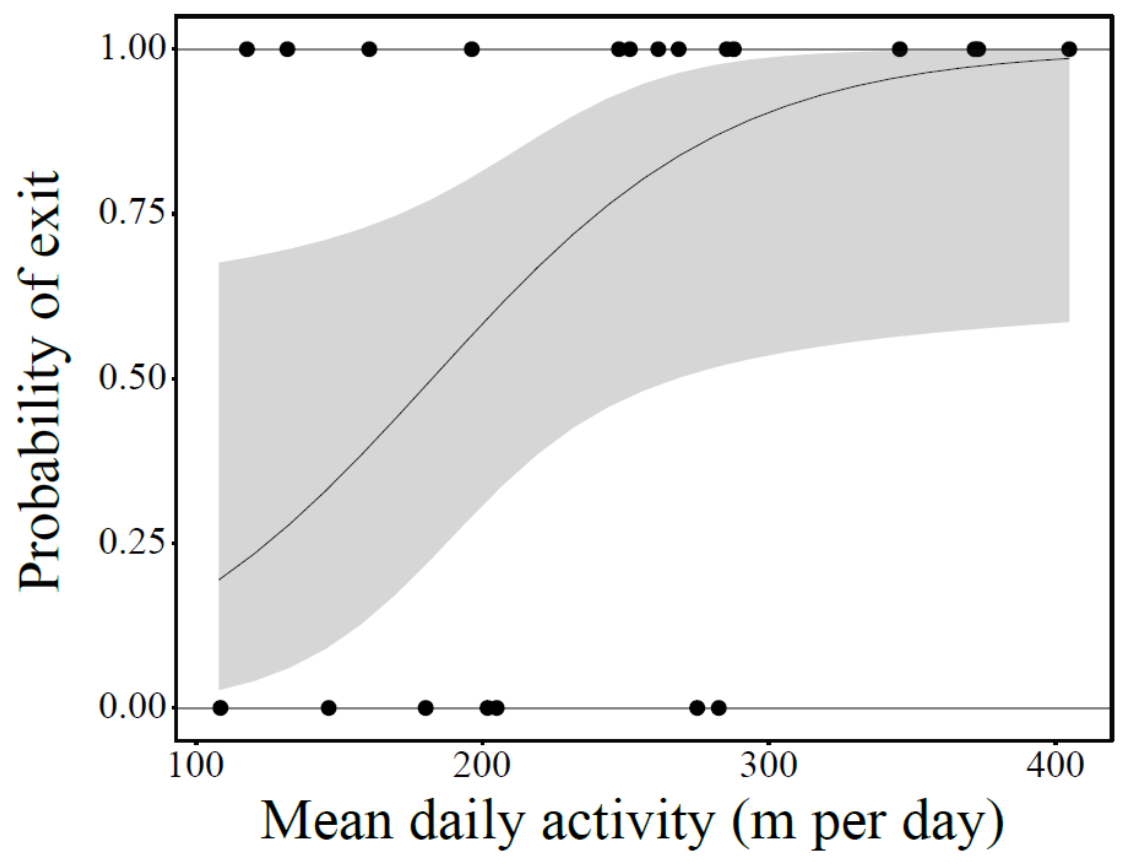

425

$426 \quad$ Figure 2

427

428

429

430

431

432 


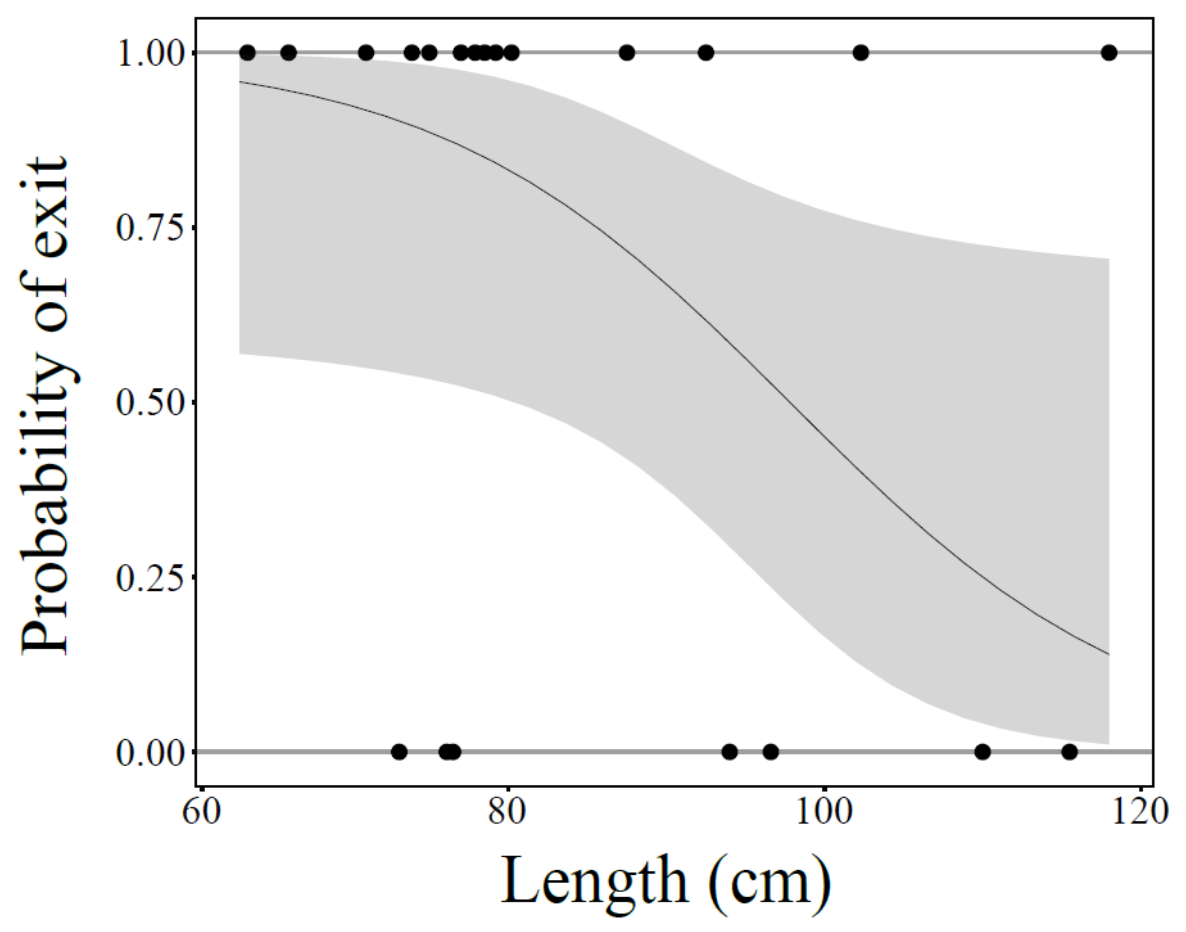

433

$434 \quad$ Figure 3 


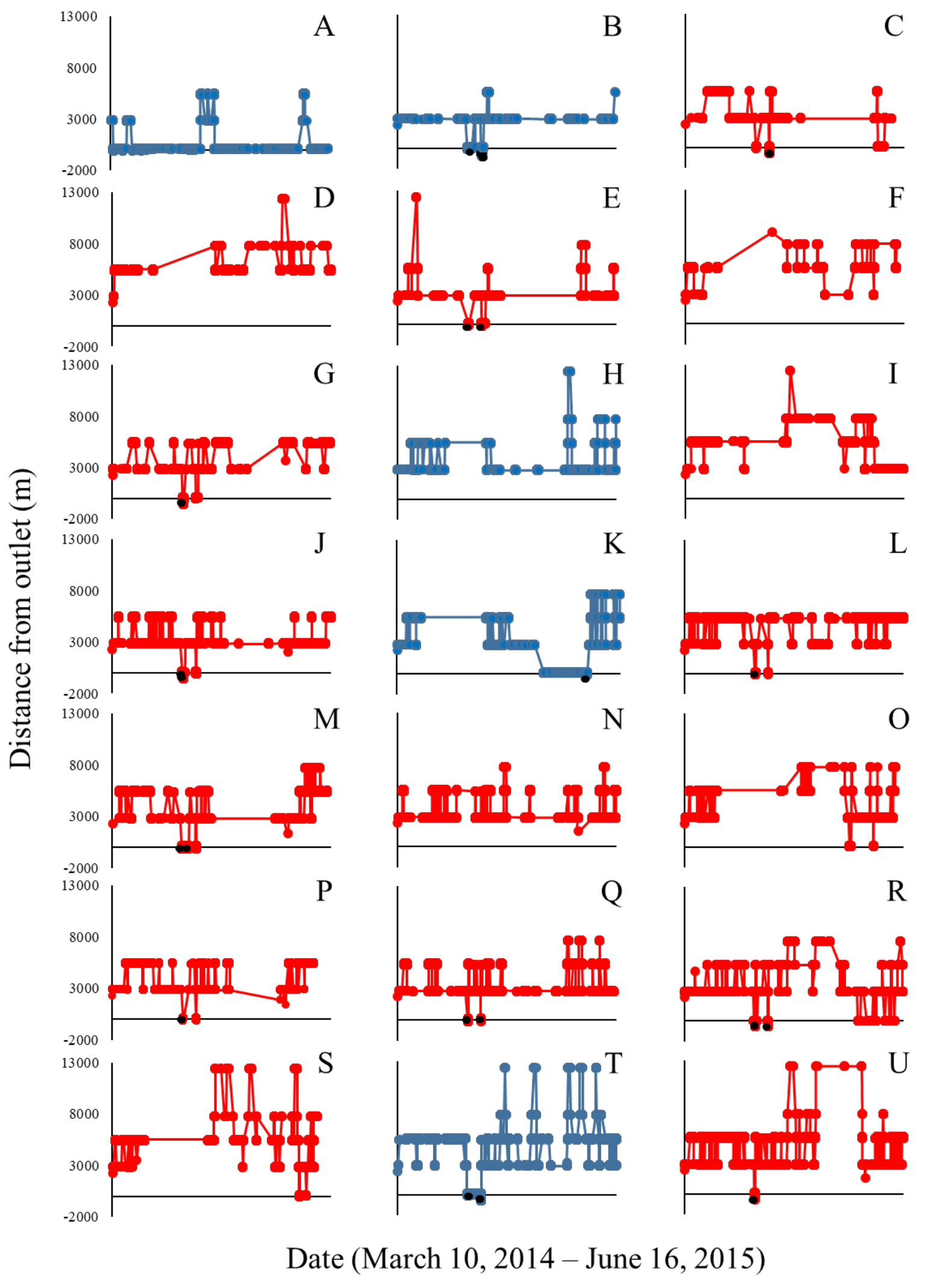

Figure 4 

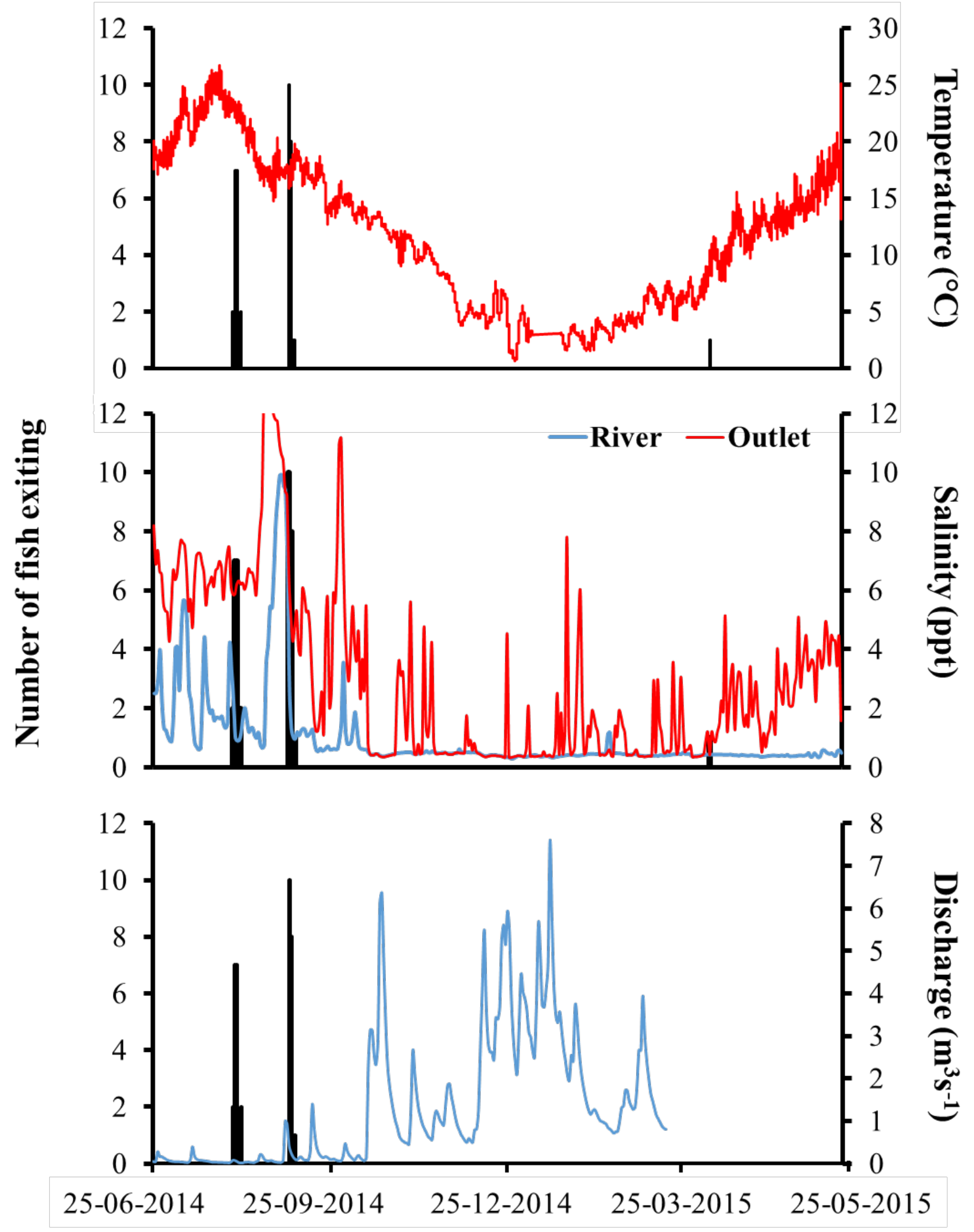

Date

$438 \quad$ Figure 5 